\title{
Pengembangan perangkat pembelajaran geometri berbasis learning trajectory berorientasi kemampuan berpikir kritis dan kreatif untuk siswa sekolah menengah pertama
}

\author{
Eka Hedayani \\ SMP Negeri 1 Tanjung Agung. Jl Liberty Simanjuntak No. 47, Muara Enim, Indonesia. \\ Corresponding Author. E-mail: eka123.hedayani@gmail.com
}

Received: 8 September 2018; Revised: 17 October 2018; Accepted: 21 December 2018

\begin{abstract}
Abstrak
Penelitian ini bertujuan untuk menghasilkan perangkat pembelajaran geometri berbasis learning trajectory yang berkualitas baik/layak digunakan dalam proses pembelajaran dan mendeskripsikan kualitas hasil pengembangan perangkat pembelajaran tersebut. Kualitas hasil pengembangan ditentukan berdasarkan pada kriteria dari Nieveen, yaitu valid, praktis dan efektif. Penelitian ini merupakan penelitian pengembangan. Model pengembangan perangkat pembelajaran dalam penelitian ini diadaptasi dari model pengembangan Plomp. Tahap-tahap yang dilakukan meliputi (1) analisis lingkungan terdiri dari analisis kondisi siswa dan analisis kajian literatur; (2) desain dan pengembangan produk; (3) penilaian. Uji coba dilaksanakan dalam tiga tahap, yaitu (1) uji coba/validasi ahli; (2) uji coba skala kecil; dan (3) uji coba skala besar/lapangan. Kevalidan produk pengembangan ditentukan oleh validasi ahli, kepraktisan produk pengembangan ditentukan oleh penilaian guru, penilaian siswa, dan persentase keterlaksanaan pembelajaran, sedangkan keefektifan produk pengembangan dilihat dari kemampuan berpikir kritis dan kreatif siswa. Penelitian ini menghasilkan perangkat pembelajaran geometri SMP berbasis learning trajectory yang berkualitas dan layak digunakan dalam proses pembelajaran. Masing-masing komponen perangkat pembelajaran tersebut memenuhi kriteria valid berdasarkan penilaian ahli, sangat praktis berdasarkan penilaian guru, siswa dan keterlaksanaan pembelajaran, serta efektif ditinjau dari kemampuan berpikir kritis dan kreatif siswa.
\end{abstract}

Kata Kunci: pengembangan, perangkat pembelajaran geometri, lintasan belajar, kemampuan berpikir kritis dan kreatif

\section{Developing a learning set based of geometry on learning trajectory for students of junior high school oriented to the student's critical and creative thinking skill}

\begin{abstract}
The purpose of this research was to produce a learning set geometry based on learning trajectory with good quality and feasible to be used in the learning process and describe the quality of the learning set development result. The quality of development outcomes was determined based on the criteria of Nieveen, that was valid, practical and effective. This research was a development research. The learning set development model in this research was adapted from the Plomp's model. The steps were (1) preliminary research which includes analysis the characteristics and background of the students and literature study, (2) design and product development, and (3) evaluation. The experiment were conducted in three stages: (1) expert validation test, (2) small scale trial and (3) large scale or field trials. The validity of product development was determined by the validation of the expert, the practically of the product development was determined by the teachers' assessment, the students' assessment, and the percentage of learning activity, meanwhile the product development effectiveness was viewed from critical and creative thinking skill of students. The result of this research was a learning set of junior high school geometry based on learning trajectory that was suitable for learning process. Each components of the learning device meets the criteria valid, very practical and effective.
\end{abstract}

Keywords: development, geometry learning set, learning trajectory, critical and creative thinking skill

How to Cite: Hedayani, E. (2018). Pengembangan perangkat pembelajaran geometri berbasis learning trajectory berorientasi kemampuan berpikir kritis dan kreatif untuk siswa sekolah menengah pertama. Pythagoras: Jurnal Pendidikan Matematika, 13(2), 158-167. doi:https://doi.org/10.21831/pg.v13i2.21242

https://doi.org/10.21831/pg.v13i2.21242 


\section{PENDAHULUAN}

Pendidikan memiliki peran penting dalam proses pembangunan suatu bangsa dan negara. Perubahan zaman akibat dari perkembangan ilmu pengetahuan dan teknologi harus disejajarkan dengan penyediaan sumber daya manusia yang berkualitas. Salah satu upaya peningkatan kualitas pendidikan yang dilakukan saat ini adalah dengan diimplementasikannya Kurikulum 2013 (K-13) yang merupakan langkah lanjutan pengembangan Kurikulum Berbasis Kompetensi (KBK) tahun 2004 dan Kurikulum Tingkat Satuan Pendidikan (KTSP) 2006 yang mencakup kompetensi sikap, pengetahuan, dan keterampilan.

Dalam Undang-Undang Nomor. 20 Tahun 2003 tentang Sistem Pendidikan Nasional menyebutkan bahwa kurikulum adalah seperangkat rencana dan pengaturan mengenai tujuan, isi, dan bahan pelajaran serta cara yang digunakan sebagai pedoman penyelenggaraan kegiatan pembelajaran untuk mencapai tujuan pendidikan tertentu. Kurikulum 2013 bertujuan untuk mempersiapkan manusia Indonesia agar memiliki kemampuan hidup sebagai pribadi dan warga negara yang beriman, produktif, kreatif, inovatif, dan afektif serta mampu berkontribusi pada kehidupan bermasyarakat, berbangsa, bernegara, dan peradaban dunia.

Untuk mencapai tujuan pembelajaran matematika tersebut diperlukan pembelajaran yang tidak hanya terfokus pada target dan kompetensi penguasaan materi, peningkatan kemampuan hafalan serta menggunakan soal-soal rutin yang ada di dalam buku pegangan siswa yang bersifat abstrak yang dimulai dengan definisi, sifat-sifat dan diakhiri dengan pemberian contohcontoh. Tujuan pembelajaran tersebut juga harus didukung dengan pembelajaran yang memberikan kesempatan pada peningkatan pemahaman konsep dan kemampuan dalam menyelesaikan permasalahan yang lebih kompleks. Diantaranya yaitu kemampuan berpikir kritis (critical thinking) dan kemampuan berpikir kreatif (creative thinking).

Menurut Beyer (1990, p.57) bahwa seorang pemikir kritis mampu untuk menentukan kredibilitas sumber; membedakan antara yang relevan dan yang tidak; membedakan fakta dari penilaian; mengidentifikasi dan mengevaluasi asumsi implisit; mengidentifikasi bias yang ada; mengidentifikasi sudut pandang dan mengevalusi bukti yang ditawarkan untuk mendukung pengakuan. Sedangkan kemampuan berpikir kreatif menurut Santrock (2014, p.11) bahwa seorang pemikir kreatif mempunyai kemampuan untuk berpikir tentang cara baru, dan tidak biasa dan datang dengan solusi yang unik. Sikap pemikir kritis dan kreatif tersebut sangat diperlukan siswa selama proses pembelajaran matematika.

Hasil wawancara yang dilakukan dengan guru di SMPN 1 Tanjung Agung menunjukkan bahwa sebagian besar siswa mempunyai masalah yang berkaitan dengan pengembangan kemampuan berpikir kritis dan kreatif mereka. Rendahnya kemampuan berpikir kritis dapat diakibatkan oleh pembelajaran yang tidak memfasilitasi siswa untuk berpikir dalam tingkat yang tinggi. Hal tersebut berakibat pada tidak terbiasanya siswa untuk menyelesaikan masalah tidak rutin dan berpikir kritis. Hal ini sejalan dengan pendapat dari Nugraha dan Mahmudi (2015, p.1). Dalam proses mengerjakan soal misalnya, banyak siswa yang belum mampu mengidentifikasi pokok permasalahan dan mengevaluasi proses penyelesaian masalah. Sejalan dengan hal tersebut, hasil penelitian Anggraeni, Ristiati dan Widiyanti (2013, p.2) menunjukkan bahwa siswa masih mengalami kesulitan dalam menyelesaikan tes berpikir kritis terutama pada indikator evaluasi berdasarkan fakta.

Mata pelajaran matematika sebagai bagian dari struktur kurikulum merupakan salah satu mata pelajaran wajib bagi siswa pada jenjang pendidikan dasar dan menengah. Salah satu aspek pada ruang lingkup mata pelajaran matematika dalam satuan pendidikan SMP adalah tentang geometri (studi tentang bangun, ukuran dan posisi). Menurut Yee dan Hoe (2009, p.226), geometri adalah salah satu cabang tertua dan paling penting dari matematika di tingkat kurikulum sekolah diseluruh dunia. Freudenthal (Yee \& Hoe, 2009, p.226) mengungkapkan bahwa ada dua aspek utama dalam pembelajaran geometri yaitu sebagai ilmu ruang dan sebagai struktur logis dimana geometri mengajarkan tentang struktur matematika. Oleh karena itu, setiap konsep-konsep pada pokok bahasan geometri tersusun secara hierarki dan memiliki keterkaitan satu sama lain.

Hudojo (2001, p.30) menyatakan bahwa setiap konsep-konsep disusun berhubungan sedemikian sehingga berurutan dan merupakan kesatuan yang utuh dan tidak dapat dipartisi. Yang artinya dalam mempelajari dan memahami konsep matematika yang baru kita memerlukan konsep matematika lainnya yang sebelumnya sudah pernah atau hendak kita pelajari. Hal ini berarti bahwa konsep-konsep tersebut memiliki 
keterkaitan satu sama lain. Dimana jika kita tidak memahami atau tidak tau salah satu konsep saja, terlebih konsep dasarnya, maka akan terjadi sebuah miskonsepsi atau timbul hambatan dalam upaya memecahkan permasalahan. Madsen, Smith dan Lanier (Yee \& Hoe, 2009, p.18), menyatakan bahwa "it is vital that the conceptual understanding of mathematics concepts be the focus of mathematics learning". Maksud kutipan tersebut adalah pemahaman konsep merupakan hal yang sangat penting karena konsep merupakan fokus dari belajar matematika.

Di Indonesia sejumlah fakta menunjukkan bahwa prestasi geometri siswa SMP masih perlu ditingkatkan. Dalam Laporan Hasil Trends in International Mathematics and Sciense Study (TIMSS) tahun 2011 disebutkan bahwa dari 43 soal geometri, rata-rata jawaban benar siswa Indonesia hanya mencapai 39\% sedangkan siswa Indonesia hanya mencapai $24 \%$. Lebih lanjut dijelaskan bahwa secara umum potensi siswa SMP di Indonesia berada dalam level rendah yaitu pada taraf mengetahui, belum mencapai taraf megaplikasikan, memahami, apalagi menalar (Mullis, Martin, Foy, \& Arora, 2012).

Dalam skala nasional, berdasarkan Laporan Hasil Ujian Nasional (UN) SMP tiga tahun berturut-turut diketahui bahwa penguasaan geometri siswa Indonesia berada pada persentase rendah yaitu pada tahun 2013/2014 mencapai 62,4; tahun 2014/2015 mencapai 52.44 dan tahun 2015/2016 menurun menjadi 47.19. Berdasarkan hasil ulangan harian untuk materi geometri kelas VII hasilnya masih banyak di bawah KKM. Berdasarkan persentase daya serap Ujian Nasional (UN) menunjukkan persentase penguasaan materi berkaitan dengan geometri ditingkat Kabupaten Muara Enim mengalami penurunan yaitu tahun 2013/2014 sebesar 80,17; tahun 2014/2015 mengalami penurunan sehingga menjadi 63,77 dan tahun 2015/2016 menurun lagi menjadi 59,75.

Berdasarkan data tersebut, ada beberapa faktor yang menyebabkan pembelajaran geometri siswa di SMP belum optimal, yaitu (1) siswa menganggap bahwa geometri merupakan pelajaran yang sulit. Berdasarkan hasil ulangan harian untuk materi geometri kelas VII hasilnya masih banyak di bawah KKM. Salah satu penyebabnya adalah rendahnya penguasaan konsep; (2) Pembelajaran terfokus pada hafalan materi/ rumus bukan pada pemahaman; (3) metode pembelajaran yang kurang sesuai dengan karakteristik materi geometri yang dipelajari; (4) guru bertindak sebagai sumber pengetahuan sementara siswa jarang memiliki pengalaman langsung berinteraksi dengan lingkungan belajar geometri; (5) pembelajaran yang tidak memperhatikan lintasan belajar siswa; (6) siswa cenderung menghafal rumus geometri namun tidak memahami cara untuk menerapkannya; dan (7) terbatasnya alat peraga dan bahan ajar geometri yang berkualitas. Maka untuk mengatasi hal tersebut perlu dilakukan upaya-upaya untuk meningkatkan penguasaan dan pemahaman siswa pada materi pelajaran yaitu dengan merancang desain pengajaran matematika yang efektif dan kegiatan pembelajaran yang baik dengan melihat learning trajectory siswa dan pemilihan strategi pembelajaran yang tepat untuk membantu siswa memiliki kompetensi matematika.

Van De Walle (2007, p.2) menegaskan bahwa untuk mencapai pendidikan matematika yang berkualitas tinggi para guru harus (1) memahami secara mendalam matematika yang mereka ajarkan; (2) memahami bagaimana siswa belajar matematika, termasuk didalamnya mengetahui perkembangan matematika siswa secara individual; (3) memilih tugas-tugas dan strategi yang akan meningkatkan mutu proses pengajaran. Ini berarti pengajaran yang efektif merupakan kegiatan yang terpusat pada siswa. Di dalam kelas yang bersifat konstruktivis, tekanan diberikan kepada pembelajaran, bukan pada pengajaran. Jadi, dalam konteks mengajar, seorang pengajar harus memiliki pengetahuan tentang konten materi yang akan diajarkan dan strategi efektif untuk menyajikan materi ajar kepada peserta didik. Sejalan dengan teori belajar Vygotsky bahwa siswa perlu mengkonstruksi suatu konsep di mana pengetahuan itu diperoleh secara individu melalui kegiatan mengkonstruksi sendiri pengetahuannya dari proses interaksi dengan obyek yang dihadapinya serta pengalaman sosial.

Uno (2008, p.85) juga menyatakan bahwa untuk memperbaiki kualitas pembelajaran perlu diawali dengan perencanaan pembelajaran. Perencanaan pembelajaran di sini dimaknai sebagai upaya merencanakan suatu desain pembelajaran yang berorientasi pada ketercapaian tujuan pembelajaran itu sendiri. Sejalan dengan hal tersebut, Marsigit (2013, p.3) mengatakan bahwa skema pembelajaran perlu dimulai dengan perencanaan yang mempertimbangkan berbagai faktor serta sumber belajar yang digunakan. Pengembangan perangkat pembelajaran, meliputi RPP dan LKS, menjadi sangat penting. Menurut Permendikbud Nomor 22 Tahun 2016 perencanaan pembelajaran dirancang dalam bentuk Silabus dan Rencana 
Pelaksanaan Pembelajaran (RPP) yang mengacu pada standar isi. Perencanaan pembelajaran meliputi penyusunan rencana pelaksanaan pembelajaran dan penyiapan media dan sumber belajar, perangkat penilaian pembelajaran, dan skenario pembelajaran. Berdasarkan hal tersebut, dapat disimpulkan bahwa salah satu penunjang upaya perbaikan kualitas pembelajaran di dalam kelas adalah perangkat pembelajaran yang baik, yang sesuai dengan prinsip dan tujuan pembelajaran.

Namun pada kenyataan dilapangan, berdasarkan wawancara dan pengisian angket terhadap beberapa guru matematika diperoleh informasi bahwa seluruh guru tidak tahu apa itu learning trajectory sehingga seluruh guru belum pernah membuat RPP yang sesuai dengan learning trajectory siswa. Selain itu, hampir seluruh guru menggunakan perangkat hasil download dan copy paste dari dari internet. Sebagian besar guru juga belum mengembangkan LKS sebagai pendukung dari silabus dan RPP. Pada umumnya, LKS yang digunakan dalam pembelajaran di sekolah hanya berupa kumpulan soal penerapan dari konsep yang diajarkan. Hal ini diperkuat oleh hasil penelitian Purwandari (2014) yang memperlihatkan bahwa masih banyak LKS yang hanya berupa kumpulan soal-soal yang digunakan sebagai kegiatan pengayaan saja, bukan sebagai kegiatan yang memfasilitasi siswa untuk mengkonstruk pemahaman mereka sendiri tentang materi yang sedang dipelajari. Padahal seharusnya LKS dibuat untuk membantu memfasilitasi siswa dalam menemukan konsep-konsep tentang materi yang sedang mereka pelajari.

Selain RPP dan LKS, silabus juga merupakan titik penting dari proses pembelajaran. Silabus merupakan acuan penyusunan kerangka pembelajaran yang berisi kegiatan antara guru dan siswa untuk setiap bahan kajian mata pelajaran dalam merelisasikan tujuan dalam pembelajaran yang akan dicapai. Silabus perlu disusun dengan baik agar hasil pembelajaran sesuai dengan apa yang diharapkan.

Untuk merencanakan suatu pembelajaran, seorang guru perlu mempertimbangkan aspek hubungan antara guru, materi, dan siswa. Guru merupakan fasilitator dalam proses pembelajaran. Hal ini dikarenakan dengan mengupayakan terjadinya suatu hubungan yang baik antara ketiganya akan menghasilkan proses pembelajaran yang efektif. Oleh karena itu guru perlu membuat hipotesis atau dugaan terkait dengan kegiatan-kegiatan yang akan dilaksanakan selama pembelajaran.
Menurut Simon dan Tzur (2014, p.91), Hypothetical Learning Trajectory (HLT) merupakan aspek kunci dari suatu perencanaan pembelajaran matematika. HLT terdiri atas tiga komponen utama yaitu: tujuan untuk siswa belajar, sekumpulan tugas untuk mencapai tujuantujuan tersebut, dan dugaan/hipotesis tentang proses pembelajaran siswa. Sejalan dengan hal tersebut, Clements dan Sarama (2009, p.4) menyatakan lintasan belajar menghubungkan penelitian (teori) dengan praktek, menghubungkan siswa dengan matematika, guru dengan siswa. Lintasan belajar membantu guru untuk mengetahui tingkat pengetahuan dan tingkat berfikir siswa di kelasnya. Jadi, guru sebaiknya memahami pengetahuan siswa, cara anak berpikir dan belajar matematika, serta bagaimana membantu siswa belajar lebih baik mengingat pentingnya pendidikan yang berkesinambungan dalam sisi konten dan proses.

Penelitian mengenai learning trajectory sudah banyak dilakukan seperti penelitian yang dilakukan oleh (Clements, Wilson, \& Sarama, 2014, pp.163-184) dimana tujuan dari penelitiannya adalah untuk menggambarkan matematika pada suatu aktivitas dan objek berupa benda yang digunakan dalam belajar geometri. Penelitian ini yang menghasilkan temuan bahwa tujuan, komponen kurikulum, penilaian dan strategi pembelajaran saling berkaitan. Sejalan dengan penelitian tersebut, Confrey, Maloney dan Corley (2014, p.13) menghasilkan temuan bahwa lintasan belajar memiliki peran besar dalam konteks permainan menggunakan benda yang bisa menghubungkan standar kurikulum, pengajaran, penilaian dan pengembangan serta berfungsi sebagai kerangka pemersatu untuk model pembelajaran. Dengan adanya learning trajectory maka dapat memfasilitasi pembelajaran matematika. Penelitian Amador dan Lamberg (2013, p.168) menghasilkan temuan bahwa pembelajaran matematika yang efektif tidak hanya melibatkan pemahaman prosedural tetapi juga pada pemahaman konseptual mengenai ide-ide matematika.

Clements dan Sarama (2009, p.3) yang menyatakan bahwa "learning trajectories have three parts: a mathematical goal, a developmental path along which children develop to reach that goal, and a set of instructional activities, or tasks, matched to each of the levels of thinking in that path that help children develop ever higher levels of thinking". Maksud dari pernyataan tersebut adalah lintasan belajar memiliki tiga bagian penting, meliputi: tujuan matematika, alur perkembangan siswa untuk 
mencapai tujuan, dan satu set kegiatan pembelajaran, atau tugas yang cocok untuk masingmasing tingkatan berpikir dalam membantu siswa mengembangkan tingkat berpikir yang lebih tinggi lagi. Ini berarti bahwa dengan learning trajectory dapat meningkatkan kemampuan berpikir siswa ke level yang lebih tinggi yaitu kemampuan berpikir tingkat tinggi (higher order thinking skills) yang salah satunya adalah kemampuan berpikir kritis dan kreatif.

Dari uraian tersebut maka dapat ditarik kesimpulan bahwa learning trajectory sangat bermanfaat dan dapat memfasilitasi pembelajaran matematika dimana setiap komponen saling berkaitan satu sama lain. Maka dari itu, untuk mengetahui lintasan belajar siswa dalam belajar matematika perlu adanya pengembangan perangkat pembelajaran yang bisa memfasilitasinya. Dengan demikian, penelitian ini bertujuan untuk menghasilkan perangkat pembelajaran berupa silabus, Rencana Pelaksanaan Pembelajaran (RPP) maupun Lembar Kerja Siswa (LKS) berbasis learning trajectory berorientasi kemampuan berpikir kritis dan kreatif siswa pada mata pelajaran matematika yang baik dan layak untuk digunakan, yaitu memenuhi kriteria valid, praktis dan efektif.

\section{METODE}

Jenis penelitian ini adalah penelitian pengembangan atau research and development. Pengembangan ini bertujuan mengembangkan produk berupa perangkat pembelajaran geometri kelas VII materi bangun datar segiempat dan segitiga berbasis learning trajectory yang terdiri dari silabus, RPP dan LKS. Penelitian ini juga dimaksudkan untuk mengetahui kualitas perangkat pembelajaran yang dikembangkan dari aspek kevalidan, kepraktisan dan keefektifan. Model pengembangan pembelajaran untuk menghasilkan perangkat pembelajaran yang dignkaan dalam penelitian ini adalah model pengembangan menurut Plomp.

Penelitian dilaksanakan pada bulan Februari sampai April 2017 di SMP Negeri 1 Tanjung Agung, Kabupaten Muara Enim, Provinsi Sumatera Selatan. Subjek uji coba dalam penelitian ini adalah siswa kelas VIII SMP Negeri 1 Tanjung Agung. Pemilihan subjek coba dilakukan dengan memilih secara acak pada 6 siswa dengan kemampuan akademik tinggi, sedang, dan rendah untuk uji coba kelompok kecil dan satu kelas dari tujuh kelas yang ada untuk uji coba lapangan. Enam siswa untuk uji coba kelompok kecil adalah siswa kelas VIII.B dan uji coba lapangan dilakukan pada siswa kelas VII.A.

Prosedur pengembangan pada penelitian ini menggunakan model pengembangan menurut Plomp yang terdiri dari 3 tahap yaitu: tahap penelitian awal (Preliminary Research), tahap desain dan pengembangan (Development or prototyping phase) dan tahap penilaian (Assessment Phase). Tahap penelitian awal terdiri dari analisis lingkungan dan kondisi siswa serta kajian literatur. Analisis ini bertujuan untuk mengetahui masalah dan alternatif terhadap pengembangan perangkat, karakteristik siswa, konsep materi geometri, hypothetical learning trajectory, teori belajar yang sesuai serta kompetensi-kompetensi dasar yang harus dicapai siswa berdasarkan Kurikulum 2013.

Pada tahap desain dan pengembangan dilakukan penyusunan perangkat pembelajaran yang berupa silabus, RPP, LKS dan tes kemampuan berpikir kritis dan kreatif. Hasil awal pembuatan perangkat pembelajaran selanjutnya dinamakan prototype 1. Revisi prototype 1 dilakukan berdasarkan masukan dan saran validator. Perangkat pembelajaran matematika yang telah direvisi berdasarkan saran/kritik dari validator disebut prototype 2. Pada tahap ini juga dilakukan penyusunan instrumen untuk menilai kriteria kepraktisan berupa lembar pengamatan keterlaksanaan pembelajaran dan angket respon guru dan siswa yang kemudian akan divalidasi oleh validator dan akan digunakan untuk uji coba lapangan.

Tahap penilaian dilaksanakan dengan melibatkan guru dan siswa di sekolah tempat penelitian. Analisis hasil uji coba pada tahap penilaian ini selanjutnya digunakan sebagai bahan revisi produk selanjutnya. Pada tahap ini juga dilakukan penilaian dengan mengisi angket respon mengenai perangkat pembelajaran matematika yang telah dikembangkan dan soal tes yang diberikan setelah seluruh kegiatan pembelajaran selesai dilaksanakan. Analisis hasil uji coba pada tahap penilaian ini selanjutnya digunakan sebagai bahan revisi produk selanjutnya. Hasil revisi berdasarkan tahap ini disebut prototype 3. Produk hasil revisi setelah tahap uji coba lapangan ini disebut prototype 4.

Adapun produk yang dihasilkan dari pengembangan yaitu perangkat pembelajaran matematika berupa silabus, RPP, LKS, dan tes kemampuan berpikir kritis dan kreatif. Instrumen penilaian yang digunakan dalam penelitian ini dapat dilihat pada Tabel 1 . 
Pythagoras, 13 (2), 2018 - 162

Eka Hedayani

Tabel 1. Instrumen Penelitian

\begin{tabular}{|c|c|}
\hline Kualitas & $\begin{array}{c}\text { Instrumen yang Digunkan untuk } \\
\text { Perangkat Pembelajaran } \\
\text { Matematika } \\
\end{array}$ \\
\hline Kevalidan & $\begin{array}{l}\text { Instrumen penilaian kevalidan } \\
\text { silabus } \\
\text { Instrumen penilaian kevalidan } \\
\text { RPP } \\
\text { Instrumen penilaian kevalidan } \\
\text { LKS } \\
\text { Instrumen penilaian kevalidan tes } \\
\text { kemampuan berpikir kritis dan } \\
\text { kreatif } \\
\text { Lembar penilaian kepraktisan } \\
\text { nembelaiaran dari ouru }\end{array}$ \\
\hline Kepraktisan & $\begin{array}{l}\text { Lembar penilaian kepraktisan } \\
\text { pembelajaran dari siswa } \\
\text { Lembar observasi keterlaksanaan } \\
\text { pembelajaran }\end{array}$ \\
\hline Keefektifan & $\begin{array}{l}\text { Tes kemampuan berpikir kritis dan } \\
\text { kreatif }\end{array}$ \\
\hline
\end{tabular}

Analisis kevalidan perangkat pembelajaran yaitu silabus, RPP, LKS dan instrumen tes kemampuan berpikir kritis dan kreatif yang sudah divalidasi ahli selanjutnya dianalisis secara deskriptif atau kualitatif. Masing-masing perangkat pembelajaran dikatakan valid apabila kevalidan minimal berada pada kriteria baik.

Adapun langkah-langkah yang digunakan untuk menentukan kriteria kevalidan perangkat adalah data berupa skor dari ahli melalui lembar validasi dijumlahkan, kemudian total skor yang diperoleh dikonversikan menjadi data kualitatif dengan 5 kriteria yaitu sangat baik, baik, cukup baik, kurang baik dan sangat kurang baik.

Analisis kepraktisan dilakukan terhadap data penilaian guru, data hasil pengisian lembar observasi kegiatan pembelajaran dan data penilaian siswa pada uji coba kelompok kecil dan uji coba lapangan. Data yang diperoleh berupa lima kategori tanggapan yaitu tidak baik, kurang baik, cukup baik, baik dan sangat baik. Instrumen dikatakan memenuhi kriteria kepraktisan jika penilaian kepraktisan dari guru minimal terkategori baik dan jika setidaknya $75 \%$ siswa memberikan penilaian kepraktisan dengan kategori minimal baik. Sedangkan produk dikatakan memenuhi kriteria kepraktisan jika tingkat keterlaksanaan pembelajaran minimal berada pada $80 \%$.

Analisis keefektifan bertujuan untuk mengetahui sejauh mana produk yang telah dikembangkan memenuhi kriteria efektif. Perangkat pembelajaran dikatakan efektif jika persentase tes kemampuan berpikir kritis dan kreatif siswa memenuhi kriteria ketuntasan belajar secara klasikal yaitu minimal $75 \%$, sesuai dengan kriteria yang berlaku di sekolah atau skor telah mencapai KKM yaitu 75 .

\section{HASIL DAN PEMBAHASAN}

Tahap penelitian awal dilakukan beberapa kegiatan yang bertujuan untuk mengumpulkan informasi mengenai masalah-masalah dasar dan kebutuhan dalam pembelajaran yang menjadi fokus penelitian yaitu analisis kondisi siswa, analisis lingkungan dan analisis kajian literatur. Analisis kondisi siswa dan lingkungan belajar dilakukan untuk mengidentifikasi masalah yang mendasari pengembangan perangkat pembelajaran matematika yang akan dilakukan. Selain itu, juga dilakukan kajian literatur untuk mendapatkan acuan dalam mengembangkan perangkat pembelajaran matematika yang dilakukan dengan cara mengkaji Standar Isi pada pembelajaran matematika SMP, khususnya pada materi pokok geometri, learning trajectory siswa dan teori belajar yang digunakan. Selain itu juga melalui diskusi, wawancara, pengumpulan kuesioner, serta observasi di lapangan untuk mengumpulkan informasi-informasi awal yang mendukung produk yang akan dikembangkan. Hasil yang diperoleh pada tahap ini mencakup 3 hal, yaitu: (1) pentingnya learning trajectory pembelajaran geometri; (2) teori belajar yang digunakan dalam pembelajaran geometri; dan (3) metode yang sesuai untuk pembelajaran geometri.

Tahap selanjutnya adalah tahap desain/ pengembangan produk. Tahapan ini mencakup pengembangan materi, pengembangan perangkat pembelajaran dan penyusunan instrumen penilaian. Kegiatan dalam pengembangan materi mencakup analisis pembelajaran dan identifikasi karakteristik siswa. Analisis pembelajaran dilakukan dengan mengidentifikasi kurikulum pembelajaran matematika SMP yang mengacu pada Peraturan Menteri. Penyusunan instrumen penilaian mengacu pada analisis materi dan karakteristik pembelajaran. Berdasarkan prototype produk awal yang diperoleh berupa perangkat pembelajaran geometri SMP yang terdiri dari silabus, RPP, LKS, dan tes kemampuan berpikir kritis dan kreatif.

Tahap selanjutnya adalah tahap penilaian yaitu melakukan uji coba terhadap produk tersebut. Tahapan uji coba ini meliputi validasi ahli, uji coba skala kecil dan uji coba skala besar/ lapangan. Proses validasi ahli melibatkan 3 (tiga) validator terdiri dari 2 (dua) orang dosen Prodi 
Pendidikan Matematika Universitas Negeri Yogyakarta dan seorang praktisi/guru mata pelajaran. Adapun dari unsur praktisi adalah guru matematika SMPN 1 Tanjung Agung. Berdasarkan kriteria kevalidan komponen perangkat pembelajaran yang telah ditetapkan dapat diketahui tingkat kevalidan masing-masing komponen perangkat pembelajaran tersebut berada pada kategori sangat valid dan valid. Data hasil analisis kevalidan perangkat pembelajaran dapat dilihat pada tabel berikut.

Tabel 2. Hasil Analisis Kevalidan Perangkat Pembelajaran

\begin{tabular}{clcc}
\hline No. & \multicolumn{1}{c}{ Komponen } & $\begin{array}{c}\text { Total } \\
\text { Skor }\end{array}$ & Kategori \\
\hline 1. & Silabus & 70 & Sangat Valid \\
2. & RPP & 115,5 & Valid \\
3. & LKS & 76,5 & Sangat Valid \\
4. & Tes kemampuan ber- & 51,5 & Valid \\
& pikir kritis dan kreatif & & \\
\hline
\end{tabular}

Tahap uji coba skala kecil melibatkan 6 siswa dengan kemampuan akademik tinggi, sedang, dan rendah, masing-masing 2 siswa yang dipilih dari 2 kelas berbeda. Keenam siswa tersebut diminta memberikan penilaian pada lembar penilaian siswa yang berkaitan dengan pertanyaan tentang LKS. Proses ini dilaksanakan pada tanggal 24 Februari 2017. Dari data yang diperoleh, diketahui bahwa penilaian siswa dalam skala kecil untuk masing-masing LKS yang dihasilkan minimal berada pada kategori sangat baik. Ini berarti LKS yang dihasilkan dikategorikan praktis dalam skala kecil. Hasil analisis kepraktisan berdasarkan penilaian siswa dalam skala kecil disajikan pada Tabel 3.

Tabel 3. Hasil Analisis Kepraktisan Berdasarkan Uji Coba Skala Kecil

\begin{tabular}{clccc}
\hline Nama & $\begin{array}{c}\text { Tingkat } \\
\text { Kemampuan }\end{array}$ & Skor & Rata-rata & Kriteria \\
\hline S1 & Tinggi & 13 & & \\
S2 & Tinggi & 13 & & \\
S3 & Sedang & 12 & 12,67 & Sangat \\
S4 & Sedang & 13 & & Baik \\
S5 & Rendah & 12 & & \\
S6 & Rendah & 13 & & \\
\hline
\end{tabular}

Tahap uji coba lapangan dilakukan untuk memperoleh data hasil observasi keterlaksanaan pembelajaran, data penilaian siswa, data penilaian guru dan data tes kemampuan berpikir kritis dan kreatif. Data-data tersebut selanjutnya digunakan untuk mengetahui kepraktisan (practicality) dan keefektifan (effectiveness) perangkat pembelajaran geometri SMP berbasis learning trajectory yang dikembangkan. Pengambilan data ini dilaksanakan dalam proses pembelajaran selama 6 (enam) minggu, pertemuan dalam bulan februari yaitu 1 minggu, pertemuan dalam bulan Maret yaitu (empat) minggu, dan 1 minggu yaitu pada bulan April 2017.

Kepraktisan perangkat didasarkan pada tingkat keterlaksanaan pembelajaran dan hasil penilaian guru dan siswa. Dari kegiatan pembelajaran LKS 1 sampai LKS 9 dan pengamatan berdasarkan aktivitas siswa yang diperoleh ada kegiatan yang tidak termasuk pada dugaan learning trajectory siswa yaitu pada kegiatan menemukan rumus jajar genjang ada siswa yang menempel gambar jajar genjang membentuk gambar segitiga. Pada kegiatan menemukan rumus trapesium membentuk gambar jajar genjang kemudian menurunkan rumus trapesium menjadi rumus jajar genjang.

Berdasarkan data hasil observasi keterlaksanaan pembelajaran selama 9 (sembilan) kali pertemuan. Diketahui bahwa persentase keterlaksanaan pembelajaran sebesar $88,44 \%$ untuk keterlaksanaan guru dan $83,67 \%$ untuk keterlaksanaan siswa. Ini berarti bahwa rata-rata persentase keterlaksanaan pembelajaran terletak pada interval 75\%-100\%. Dengan demikian dapat disimpulkan bahwa keterlaksanaan pembelajaran menggunakan perangkat pembelajaran geometri SMP berbasis learning trajectory yang dihasilkan di lapangan memenuhi kategori sangat baik. Ini berarti perangkat pembelajaran geometri SMP berbasis learning trajectory yang dihasilkan memenuhi kategori sangat praktis untuk digunakan

Kepraktisan juga didasarkan dari hasil penilaian guru. Dari data skor penilaian guru setelah melaksanakan proses pembelajaran dengan produk perangkat hasil pengembangan, diketahui bahwa total skor penilaian yang diperoleh adalah 148. Berdasarkan kriteria kepraktisan menurut penilaian guru yang telah ditetapkan, produk hasil pengembangan memenuhi kategori sangat baik. Data kepraktisan perangkat berdasarkan penilaian guru disajikan pada Tabel 4 .

Tabel 4. Kepraktisan Perangkat Berdasarkan Penilaian Guru

\begin{tabular}{lc}
\hline \multicolumn{1}{c}{ Aspek yang Dinilai } & Rata-Rata Skor \\
\hline Silabus & 35 \\
RPP & 35 \\
LKS & 36 \\
Pelaksanaan Pembelajaran & 18 \\
Aktifitas Siswa & 24 \\
Skor Total & 148 \\
\multicolumn{1}{c}{ Kategori } & Sangat Baik \\
\hline
\end{tabular}


Di samping penilaian guru, kepraktisan juga didasarkan pada penilaian siswa. Berdasarkan data skor penilaian siswa pada akhir pertemuan diketahui bahwa persentasenya adalah 94,8\% (sangat baik), dengan persentase banyak siswa yang menilai minimal baik sebesar $2,56 \%$. Dari data skor penilaian siswa setelah keseluruhan proses pembelajaran berakhir diketahui rata-ratanya 12,79 (sangat baik). Berdasarkan hasil analisis data tersebut diketahui bahwa ratarata skor penilaian siswa selama proses dan di akhir pembelajaran memenuhi kategori sangat baik dengan persentase banyak siswa yang menilai sangat baik melebihi $80 \%$. Hal ini menunjukkan bahwa perangkat pembelajaran geometri SMP berbasis learning trajectory yang dihasilkan memenuhi kriteria praktis.

Berdasarkan hasil analisis data observasi keterlaksanaan pembelajaran, penilaian guru dan penilaian siswa, dapat disimpulkan terdapat konsistensi penilaian yang baik/positif dari guru dan siswa serta tingkat keterlaksanaan pembelajaran yang tinggi di lapangan. Hal ini menunjukkan bahwa perangkat pembelajaran geometri SMP berbasis learning trajectory yang dihasilkan memenuhi kriteria praktis untuk digunakan.

Analisis data keefektifan didasarkan pada data tes kemampuan berpikir kritis dan kreatif siswa meliputi kuis. Ringkasan hasil analisis berdasarkan data nilai tes kemampuan berpikir kritis dan kreatif tersebut disajikan pada Tabel 5. Dari Tabel 5 diketahui bahwa dari 39 siswa, terdapat 30 siswa yang tuntas KKM. Dengan ratarata 75 dan persentase ketuntasan adalah 76,92\%.

Tabel 5. Hasil Analisis Tes Kemampuan Berpikir Kritis

\begin{tabular}{lc}
\hline \multicolumn{1}{c}{ Deskripsi } & Angka \\
\hline Banyak Siswa & 39 \\
Nilai tertinggi & 95 \\
Nilai terendah & 50 \\
Nilai rata-rata & 75 \\
Jumlah siswa Tuntas & 30 \\
Jumlah siswa Tidak Tuntas & 9 \\
Persentase Ketuntasan & $76,92 \%$ \\
\hline
\end{tabular}

Tabel 6. Hasil Analisis Tes Kemampuan Berpikir Kreatif

\begin{tabular}{lc}
\hline \multicolumn{1}{c}{ Deskripsi } & Angka \\
\hline Banyak Siswa & 39 \\
Nilai tertinggi & 100 \\
Nilai terendah & 50 \\
Nilai rata-rata & 78,08 \\
Junlah siswa Tuntas & 32 \\
Junlah siswa Tidak Tuntas & 7 \\
Persentase Ketuntasan & $82,05 \%$ \\
\hline
\end{tabular}

Dari Tabel 6 diketahui bahwa dari 39 siswa, terdapat 32 siswa yang tuntas KKM. Dengan rata-rata 78,08 dan persentase ketuntasan adalah $82,05 \%$.

Berdasarkan data hasil analisis tersebut diperoleh kesimpulan bahwa ada siswa yang kemampuan berpikir kritisnya tinggi tetapi kemampuan berpikir kreatifnya rendah, ada siswa yang kemampuan berpikir kritisnya rendah tetapi kemampuan berpikir kreatifnya tinggi, ada siswa yang kemampuan berpikir kritis dan kemampuan berpikir kreatifnya tinggi, dan ada juga siswa yang kemampuan berpikir kritis dan kreatifnya rendah. Secara keseluruhan dikatakan bahwa kemampuan berpikir kritis dan kreatif setelah proses pembelajaran menggunakan perangkat yang dihasilkan telah memenuhi yaitu persentase ketuntasan siswa secara klasikal memenuhi $\mathrm{KKM} \geq 75 \%$ yang ditetapkan. Dengan demikian perangkat pembelajaran geometri SMP berbasis learning trajectory yang dihasilkan telah memenuhi kriteria efektif.

Berdasarkan hasil uji coba pada tahap sebelumnya, selanjutnya dilakukan revisi terhadap perangkat pembelajaran geometri SMP berbasis learning trajectory yang dihasilkan. Revisi dilakukan sebanyak 3 (tiga) kali berdasarkan hasil dari masing-masing uji coba. Revisi I dilakukan berdasarkan hasil uji coba ahli/validasi ahli. Revisi II dilakukan berdasarkan hasil uji coba kelompok kecil. Yang terakhir, revisi III dilakukan berdasarkan hasil uji coba lapangan, meliputi penilaian guru dan siswa dari kelas uji coba lapangan, serta keterlaksanaan pembelajaran di kelas uji coba lapangan. Hasil revisi III selanjutnya digunakan sebagai dasar menyusun produk akhir pengembangan.

Revisi I dilakukan berdasarkan saran/ masukan validator dari hasil uji coba ahli. Revisi atau perbaikan dilakukan terhadap produk pengembangan berupa perangkat pembelajaran geometri SMP berbasis learning trajectory yang telah dihasilkan, meliputi silabus, RPP, LKS dan tes kemampuan berpikir kritis dan kreatif. Secara ringkas saran/masukan validator yang dijadikan sebagai dasar revisi I Adapun revisi nya adalah revisi silabus yang dilakukan menyesuaikan penilaian dengan RPP. Revisi RPP yang dilakukan memperbaiki langkah-langkah pembelajaran, memperbaiki beberapa kegiatan pada RPP agar lebih eksplisit terutama dugaan respon guru dan siswa, memperbaiki bahasa yang masih belum sesuai dengan EYD dalam RPP, kekonsistenan dalam penggunaan kalimat perintah dalam LKS, misalkan "mengkomunikasikan" diganti dengan 
kata "mengomunikasikan", dan menambah keterangan kegiatan agar kegiatan yang dilakukan menjadi lebih jelas dan terarah. Revisi LKS yang dilakukan Perlu perbaikan pada struktur LKS yaitu penulisan disesuaikan dengan EYD, menambah keterangan kegiatan dan gambar pada LKS agar kegiatan yang dilakukan menjadi lebih jelas dan terarah, dan Memperbaiki redaksi kalimat pada mengamati masalah. Dan revisi tes kemampuan berpikir kritis dan kreatif yang dilakukan adalah Perlu perbaikan pada redaksional beberapa soal dan beberapa gambar.

Revisi II dilakukan berdasarkan hasil uji coba skala kecil. Kegiatan ini dilakukan dengan cara meminta beberapa siswa berdasarkan kategori prestasi akademik tinggi, sedang, dan rendah untuk menilai dan memberikan masukan atas produk pengembangan yang berupa LKS. Berdasarkan hasil dari kegiatan ini dilakukan revisi atau perbaikan produk pengembangan berupa LKS sebagai komponen pendukung perangkat pembelajaran geometri SMP berbasis learning trajectory yang telah dihasilkan. Beberapa revisi yang dilakukan pada tahap ini adalah memperbesar ukuran gambar pada LKS 1 dan menjadikan kegiatan membuat kreasi/hiasan menjadi tugas proyek dikarenkan waktu yang tersedia kurang.

Revisi III dilakukan berdasarkan saran/ masukan guru dan hasil pengamatan di lapangan dalam uji coba lapangan. Adapun revisi pada RPP adalah memberikan kegiatan tambahan dalam pembelajaran, yaitu meminta siswa menyiapkan kertas untuk mencari sifat-sifat segiempat dan menambahkan learning trajectory siswa yang ditemukan. Pada LKS revisi yang dilakukan adalah memperbaiki pertanyaan arahan agar siswa dapat mengumpulkan informasi dalam LKS, memperbesar ukuran gambar pada LKS 1, pada kegiatan membuat kreasi/hiasan yang berbeda dari gambar yang telah disediakan agar siswa mudah untuk menyusunnya dan memindahkan letak gambar di kegiatan 1 di pada LKS 9 sehingga pemerolehan konsep pada kegiatan tersebut menjadi runtut dan berkesinambungan.

Tahap terakhir yaitu kajian produk akhir adalah tahap penyusunan perangkat pembelajaran geometri SMP berbasis learning trajectory untuk kelas VII berdasarkan revisi terkahir. Hasil dari tahapan ini selanjutnya menjadi produk akhir, yaitu perangkat pembelajaran geometri SMP berbasis learning trajectory untuk kelas VII semester II yang valid dan layak untuk digunakan.
Catatan penting dalam pelaksanaan pembelajaran geometri SMP berbasis learning trajectory dalam proses pembelajaran adalah dalam belajar geometri harus mengikuti pola learning trajectory dimana terdapat konsep materi yang saling berkaitan dan saling berhubungan satu sama lain sehingga apabila sudah mendapatkan satu konsep maka konsep tersebut bisa menjadi konsep selanjutnya. Adapun pola learning trajectory yang baik dalam materi segiempat dan segitiga yaitu persegi panjang, persegi, segitiga siku-siku dan segitiga sebarang. Setelah dari segitiga sebarang maka bisa menentukan bangun yang lain karena jajar genjang, trapesium, belah ketupat dan layang-layang bisa dipartisi menjadi dua buah segitiga sebarang. Selain itu, kegiatan diskusi, tanya jawab dan mempresentasikan hasil diskusi masih banyak siswa yang belum berperan aktif serta pemberian tugas mandiri/PR oleh guru. Kegiatan siswa tersebut dikarenakan siswa belum terbiasa melaksanakan proses pembelajaran dengan sistematis menggunakan metode tertentu yang memberikan kesempatan luas kepada siswa untuk membangun pengetahuannya. Sedangkan tahapan guru memberikan tugas mandiri/PR yang keterlaksanaannya masih rendah disebabkan oleh pemanfaatan waktu pada beberapa pertemuan yang belum efektif.

Berdasarkan kajian tersebut dapat disimpulkan bahwa hasil pengembangan perangkat pembelajaran geometri SMP berbasis learning trajectory menggunakan pendekatan saintifik untuk kelas VII telah teruji kevalidan, kepraktisan, dan keefektifannya. Hasil analisis menunjukkan bahwa kualitas produk adalah baik, karena terbukti valid, praktis, dan efektif. Dengan demikian produk dapat digunakan dalam pembelajaran dan dapat digunakan sebagai contoh pada pengembangan pembelajaran matematika dengan melihat learning trajectory siswa yang menggunakan metode dan materi pembelajaran yang lain. Hasil penelitian tersebut sejalan dengan penelitian yang telah dilakukan oleh Sulistyani \& Retnawati (2015), bahwa untuk penelitian pengembangan perangkat pembelajaran bangun ruang di SMP dengan pendekatan problem-based learning menghasilkan perangkat pembelajaran yang valid, praktis dan efektif. Selain itu, dalam penelitian ini juga ditemukan bahwa dengan melihat learning trajectory siswa, maka pembelajaran menjadi lebih terarah dan dapat mengasah kemampuan berpikir kritis dan kreatif siswa. Hal ini tentunya sejalan dengan temuan Retnawati (2017), bahwa menggunakan learning trajectory merupakan salah satu aspek penting untuk me- 
ningkatan keterampilan peserta didik dalam memahami suatu konsep.

\section{SIMPULAN}

Berdasarkan hasil penelitian diperoleh simpulan sebagai berikut: (1) produk perangkat pembelajaran geometri berbasis learning trajectory yang dihasilkan berupa Silabus, Rencana Pelaksanaan Pembelajaran (RPP) dan Lembar Kegiatan Siswa (LKS) telah melalui validasi ahli dan dapat disimpulkan bahwa perangkat pembelajaran yang dikembangkan memenuhi kriteria valid dan sangat valid sehingga layak untuk digunakan; (2) kriteria kepraktisan perangkat pembelajaran yang dikembangkan berupa Silabus, Rencana Pelaksanaan Pembelajaran (RPP) dan Lembar Kegiatan Siswa (LKS) memenuhi kriteria praktis ditinjau dari penilaian guru, penilaian siswa dan keterlaksanaan pembelajaran; (3) perangkat pembelajaran berupa Silabus, Rencana Pelaksanaan Pembelajaran (RPP) dan Lembar Kegiatan Siswa (LKS) telah memenuhi kriteria efektif ditinjau dari kemampuan berpikir kritis dengan persentase siswa tuntas sebesar 76,92\% dan kemampuan berpikir kreatif dengan persentase siswa tuntas sebesar $82,05 \%$.

Beberapa saran yang perlu dipertimbangkan untuk peningkatan kualitas pembelajaran matematika sekolah, yaitu: (1) produk pengembangan dalam penelitian ini dapat dijadikan sebagai salah satu alternatif perangkat pembelajaran yang dapat digunakan dalam pembelajaran matematika serta dapat dijadikan sebagai referensi dan pedoman bagi guru untuk mengembangkan perangkat pembelajaran serupa pada materi lain; (2) guru hendaknya membiasakan setiap siswa untuk belajar menyampaikan pendapat, bertanya atau menanggapi pertanyaan-pertanyaan yang diberikan oleh guru agar diskusi berjalan dengan lancar, serta guru juga perlu membiasakan siswa untuk mengerjakan soal yang merangsang dan menantang siswa sehingga kemampuan berpikir kritis dan kreatif juga lebih terasah; (3) perlu dilakukan penelitian serupa dengan menggunakan populasi yang lebih besar, sehingga hasil penelitian yang diharapkan akan semakin baik.

\section{DAFTAR PUSTAKA}

Amador, J., \& Lamberg, T. (2013). Learning Trajectories, lesson planning, affordences, and constraints in the design and enactment of mathematic teaching. Mathematical Thingking and Learning, 15(2), 146-170.
Anggraeni, N., Ristiati, N., \& Widiyanti, N. (2013). Implementasi strategi pembelajaran inquiri terhadap kemampuan berfikir kritis dan pemahaman konsep IPA siswa SMP. E-Journal Program Pascasarjana Universitas Pendidikan Ganesha Program Studi IPA, 3, 1-11.

Beyer, B. K. (1990). What philosophy offers to the teaching of thinking. Educational Leadership, 47(5), 55-60.

BSNP. (2014) Laporan hasil ujian nasional tahun pelajaran 2013/2014.

BSNP. (2015) Laporan hasil ujian nasional tahun pelajaran 2014/2015.

BSNP. (2016) Laporan hasil ujian nasional tahun pelajaran 2015/2016.

Clements, D. H., Wilson, D. C., \& Sarama, J. (2014). Young children's composition of geometric figures: A learning trajectory. Mathematical Thinking And Learning, 6(2), 163-184.

Clements, D. H., \& Sarama, J. (2009). Learning and teaching early math: The learning trajectories approach. New York, NY: Routledge.

Confrey, J., Maloney, A. P., \& Corley, A. K . (2014). Learning trajectories: A framework for connecting standards with curriculum. ZDM Mathematics Education, 46(5), 719-733.

Hudojo, H. (2001). Pengembangan kurikulum dan pembelajaran matematika. Malang: Universitas Negeri Malang.

Kemendikbud. (2016). Peraturan Menteri Pendidikan Nasional Nomor 22, Tahun 2016, tentang Standar Proses Pendidikan Dasar Dan Menengah.

Marsigit. (2013). Pendekatan saintifik dan implementasinya dalam Kurikulum 2013. Paper presented in Workshop Implementasi Pendekatan Saintifik dalam Pelaksanaan Kurikulum 2013 Sabtu 13 Oktober 2015.

Mullis, I. V. S., Martin, M. O., Foy, P., \& Arora, A. (2012). TIMMS 2011: International results in mathematics. Boston, MA: TIMSS \& PIRLS International Study Center.

Nieveen, N. (1999). Prototyping to reach product quality. in Akker, J., Branch, R. M., Gustafson, K., et al. (Eds.), Design approaches and tools in education and 
training (pp. 126-135). Dordrecht, The Netherlands: Kluwer Academic Publishers.

Nugraha, T., \& Mahmudi, A. (2015). Keefektifan pembelajaran berbasis masalah dan problem posing ditinjau dari kemampuan berpikir logis dan kritis. Jurnal Riset Pendidikan Matematika, 2(1), 107 - 120. doi:https://doi.org/10.21831/jrpm.v2i1.71 54

Plomp, T. (2013). Educational design research: an introduction. in T. Plomp \& N. Nieveen (Eds), Educational design research: Part A (pp 10-51). Enschede, Netherland: SLO.

Purwandari, Y. (2014). Pengembangan perangkat pembelajaran saintifik menggunakan pendekatan kontekstual berorientasi pada kemampuan komunikasi matematis siswa kelas VII. Tesis, Universitas Negeri Yogyakarta, Yogyakarta.

Retnawati, H. (2017). Learning trajectory of item response theory course using multiple software. Olympiads in Informatics, 11, 123-142. doi: 10.15388/ioi.2017.10

Santrock, J. W., (2014). Educational psycology. New York, NY: McGraw-Hill Companies.

Simon, M. A., \& Tzur, R. (2014). Explicating the role of mathematical tasks in conceptual learning: An elaboration of the hypothetical learning trajectory. Mathematical Thinking And Learning. 6(2), 91-104.

Sulistyani, N., \& Retnawati, H. (2015). Pengembangan perangkat pembelajaran bangun ruang di SMP dengan pendekatan problem-based learning. Jurnal Riset Pendidikan Matematika, 2(2), 197 - 210. doi:https://doi.org/10.21831/jrpm.v2i2.73 34
Uno, H. B. (2008). Perencanaan pembelajaran. Jakarta: Bumi Aksara.

Van de Walle, J. A. (2007). Elementary and middle school mathematics: Teaching developmentally. $\left(6^{\text {th }} \mathrm{ed}\right)$. Paris, France: Pearson Education.

Yee, L. P., \& Hoe, L. N. (2009). Teaching secondary school mathematics: A resource book. Singapore: McGraw-Hill.Gronlund, N.E. \& Linn, R.L. (1990). Measurement and evaluation in teaching. $\left(6^{\text {th }} e d.\right)$. New York: Macmillan.

Effendi, S. (1982). Unsur-unsur penelitian ilmiah. Dalam Masri Singarimbun (Ed.). Metode penelitian survei. Jakarta: LP3ES.

Daniel, W.W. (1980). Statistika nonparametrik terapan. (Terjemahan Tri Kuntjoro). Jakarta : Gramedia.

Suyanto, S (2009). Keberhasilan sekolah dalam ujian nasional ditinjau dari organisasi belajar. Disertasi, tidak dipublikasikan. Universitas Negeri Jakarta.

Pritchard, P.E. (1992). Studies on the breadimproving mechanism of fungal alphaamylase. Journal of Biological Education, 26 (1), 14-17.

Retnawati, H. (2014). Teori respon butir dan penerapannya. Yogyakarta: Nuha Medika.

Ferita, R., \& Retnawati, H. (2016). Pengembangan Perangkat Penilaian Autentik untuk Pembelajaran Matematika di Kelas VII Semester 1. Pythagoras: Jurnal Pendidikan Matematika, 11(1), 6976.

doi:https://doi.org/10.21831/pg.v11i1.967 2 